\title{
THE MOTIVES FOR JAPANESE FOREIGN DIRECT INVESTMENT IN THE UNITED STATES SOUTHEAST
}

\begin{abstract}
Purpose

While the United States is still the largest investment destination for Japanese companies, Japan also accounts as the second largest source of investment in the country. This study empirically examines the detailed motives of Japanese affiliates when investing in the United States Southeast, adding to previous research at the national level.
\end{abstract}

\section{Methodology}

This paper uses a qualitative approach based on interviews of long-term Japanese investors in the manufacturing and wholesale trade industries in the United States Southeast, and applies text analysis to identify their motives.

\section{Findings}

Results show that Japanese firms engage in market- and efficiency-seeking FDI, and still apply a classic sequence of gradual and incremental market commitments. Market size and growth rate, reducing transaction or transportation costs, and integration within local value-chains are the most important to them, while competition, creating an export base, lowering tax and accessing skilled labor are of little concern.

\section{Practical implications}

The goal of Japanese FDI in the US is no longer to bypass tariffs but is still part of a complex industrial network of relations which drives further investment. This result can inform policy-makers at the state level about the factors that can drive additional foreign investment, such as the establishment of industrial clusters.

\section{Originality}

This study offers current insights into the motives of Japanese FDI in two industries.

\section{Keywords:}

FDI; Motives; Japan; United States

\section{INTRODUCTION}

In comparison to the 1980s, interest in Japanese business and business practices has waned considerably. In the "lost decades" of the 1990s and 2000s, Japan's once-vaunted corporate icons have been humbled, losing market share, merging, and sometimes being acquired by foreign competitors. These challenges include a long phase of sluggish economic growth following the bursting of the speculative bubble in the early 1990s (Siddiqui, 2009), a public debt equivalent to about $250 \%$ of Gross Domestic Product (GDP) making it the world's largest (Trending Economics, 2019), and dogged demographic problems of a low birthrate and a dramatically aging population (Kitao, 2015).

Japan's regional competitors have grown in the interim, particularly China, which overtook Japan as the country with the world's second-largest nominal GDP almost 10 years 
ago (Barboza, 2010). The 2011 Tohoku crisis not only killed more than 15,000 people, it also destroyed homes and factories, and the resultant Fukushima nuclear crisis damaged the country's reputation for stability and predictability.

Japan's overseas investment push precedes the current crises, however. Japan's export-led growth model (Murphy, 2010) was complemented by outward foreign direct investment (FDI), itself facilitated by globalization. Japan's post-war economic growth and political stability allowed it to take advantage of falling economic and legislative barriers to invest abroad. These changing externalities have reduced market inefficiencies. The field of international business (IB) argues that the raison d'être for multinational enterprises (MNEs) is their ability to exploit those market inefficiencies (Caves, 1971) to reduce costs, improve quality, and accelerate innovation (Hymer, 1976; Buckley and Casson, 1976).

Japanese firms have used FDI as a method to bypass imperfections and exploit market opportunities through internal operations. Data from the Japan External Trade Organization (JETRO) indicates that Japan's outward investments have increased steadily over the past 20 years, with an annualized growth rate of about 9.1\%, while Japan's GDP has contracted by $0.5 \%$ over the same period (JETRO, 2018). Japan's two highest recorded years of FDI were 2016 (USD 174 billion) and 2017 (USD 169 billion) respectively. Over almost the same period, between 1996 and 2016, Japan's exports of goods and services in constant 2010 US dollar, went from USD 438 billion to USD 981 billion, registering a year-on-year growth rate of about 3.9\%, less than half than that of outward investment (World Bank, 2018). It has therefore become clear that the growth of Japanese firms originates today more from outward investment than exports.

\section{FIGURE 1}

Japan's outward foreign direct investment by country/region (Source: JETRO, 2018)

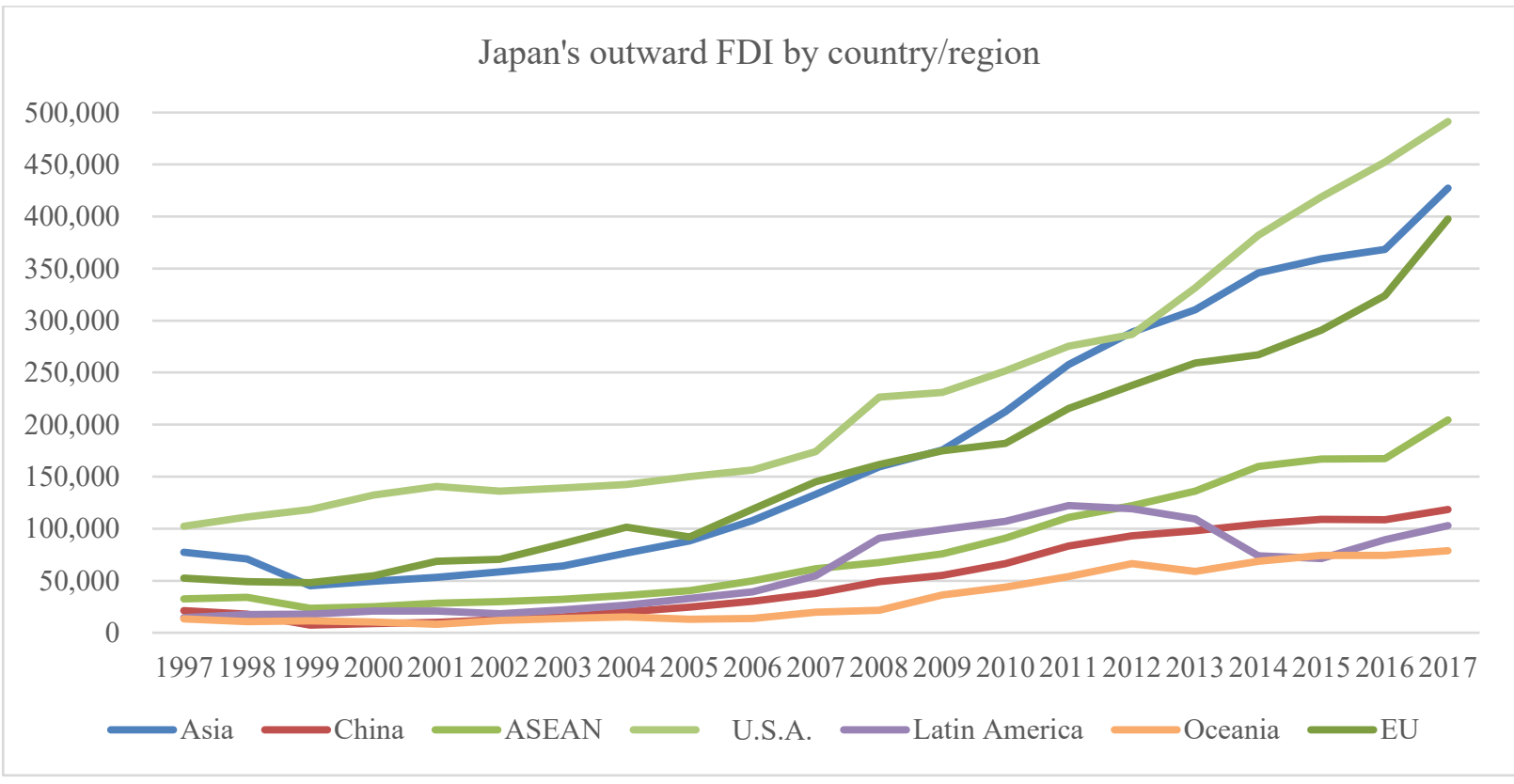

Japan has consistently ranked as a top-three source of foreign direct investment in the United States (US) economy, after the United Kingdom (Cortez, 2017). Japan is by far the largest holder of FDI stock from the Asia-Pacific region (BEA, 2017). The US remains the largest investment destination for Japanese FDI, attracting about 30\% of total Japanese 
investment, or USD 491 billion out of the stock of USD 1.55 trillion as of 2017 (JETRO, 2018).

While the IB literature on FDI motives is abundant, firms from countries undergoing structural changes, such as Japan, should be re-examined periodically so as to verify whether their motivations fit prevailing norms. Drake and Caves (1992) contended that the antecedents of Japan's involvement in foreign investment in the US had become comparable to those of Western countries. The surge in Japan's export stimulated outward FDI, as did the rhetoric and actions of the US government towards reducing Japanese exports to the country. Japan's move toward knowledge-based work has led to higher Japanese FDI in research-intensive industries. More recently, Hennart (2016) singled out Japanese firms whose investments have not always conformed to mainstream theories and argued for more research on FDI.

This paper aims to examine the motives and entry mode sequence of Japanese investors in the US Southeast using a qualitative methodology and focusing on the manufacturing and wholesale trade industries. The next section reviews the literature on the determinants of FDI and on the rationale for different entry modes. Section three details the methodology of the study and presents its findings. Last, section four discusses the results and policy implications, and provides avenues for future research.

\section{LITERATURE REVIEW}

\section{FDI Motives}

FDI is undertaken for reasons embodied in the three major logics of market imperfection theory, international production theory (eclectic paradigm), and internalization theory (Morgan and Katsikeas, 1997). The market imperfections theory states that firms invest abroad to capitalize on certain capabilities not shared by competitors in foreign countries (Hymer, 1970). The international production theory postulates that foreign production seeks specific advantages in target countries (Dunning, 1980). And last, internalization theory asserts that firms attempt to internalize most market transactions to reduce costs (Buckley, 1982, 1988).

Transaction costs and cultural factors are important factors for FDI, but only in initial entry. Over time, other determinants rise to the top (Chang and Rosenzweig, 2001). Another perspective recommended by Brouthers and Hennart (2007) is the resource-based view (RBV) (Barney, 1991). RBV can be considered as responding to the internalization theory since it posits that firms attempt to leverage their assets or resources by internalizing those operations in foreign markets. The emphasis of RBV is on knowledge as a critical resource for successful internationalization. The literature on FDI determinants is vast and considers a wide range of indicators. According to a meta-analysis of foreign market entry research, the key contextual dimensions examined in past research consist of home markets (factors of production, institutions), host markets, psychic distance (cultural and geographic distance), industry, and firm age (Laufs and Schwens, 2014).

The international production theory, mentioned above and one of the most enduring models, maintains that MNEs go abroad in the pursuit of three specific sources of advantages, ownership, location, and internalization (Dunning, 1977, 1981). Ownership advantages indicate that some firms have internal advantages over other firms to go overseas, and that these can readily transfer these advantages within the organization and overseas without losing value and without significant transaction costs. Location advantages derive from the benefits of some foreign investments made in response to demands for providing products or services locally, circumventing trade barriers, reducing transport costs, obtaining inexpensive 
inputs, or producing closer to clients or consumers. Internalization advantages denote the establishment mode of firms abroad to overcome market imperfections (Magnier-Watanabe and Lemaire, 2018). For Dunning (1993, 1998), the motives for FDI fall generally in four categories: market-seeking, resource-seeking, efficiency-seeking, and strategic asset-seeking FDI.

Market seekers undertake FDI in order to increase the size of their market. They often respond to waning demand and therefore increased competition at home, to aggressive competitors expanding or the desire to gain a first-mover advantage. They may also follow customers, seek to fill a foreign market's unmet demand, or simply benefit from a large or growing market. Kogut and Chang (1991) remarked that industry growth and R\&D expenditures attracted Japanese entry, while higher levels of seller concentration deterred it.

Resource seekers invest abroad in order to gain access to key resources for their business. Typically, these firms are looking to create an export base to other countries, to access cheaper and more abundant production input, to seek out attractive institutional and legal environments, or to take advantage of solid infrastructure. In a recent study of Japanese affiliates in 59 countries, Hong, Lee, and Makino (2018) found that natural resource-seeking and labor resource-seeking were important motives for Japanese FDI.

Efficiency seekers strive for economies of scale and scope by frequently evaluating ways to lower their total tax burden or currency exposure, to diversify risks, to avoid trade barriers, to benefit from foreign government investment incentives, to capitalize on differences in consumer patterns between countries, to integrate within existing value-chains, or to reduce transaction or transportation costs with a physical presence. Froot and Stein (1991), and Mihut (2014) found that increases in Japanese FDI in the US in the 1980s followed the appreciation of the yen relative to the dollar following the Plaza Accord of 1985, forcing Japanese companies to invest locally rather than solely rely on exports.

Strategic asset seekers engage in FDI to obtain firm-specific assets they not yet possess and believe is more to acquire rather than develop internally. Their ambitions can involve accessing skilled labor, gaining knowledge about a target market, reducing or preventing competition by acquiring whole or part of a company, diversifying their product portfolio, or gaining specific technological knowledge. Japanese joint-ventures were deemed to be often motivated by their desire to source US technology (Kogut and Chang, 1991).

While market and resource-seeking FDI are more prevalent in firms at an early stage of internationalization, efficiency and strategic-asset FDI are especially common in firms already established abroad and furthering their international growth (Dunning, 2000). Japanese firms are therefore predicted to engage in more efficiency and strategic-asset seeking FDI in a later stage of internationalization (Hypothesis 1).

\section{Market entry modes}

The internationalization of Japanese firms and their entry into the US market follow both international trade and FDI logics. International trade theories suggest that firms go through different stages in the process of export development (Rao and Naidu, 1992), ranging from domestic market-only focus to committed export involvement. However, export often constitutes the first stage of internationalization and is quickly followed by FDI. Research from the Uppsala School (Johanson and Wiedersheim-Paul, 1975) has shown that "the process of internationalization is founded on an evolutionary and sequential build-up of foreign commitments over time" (Morgan and Katsikeas, 1997, p. 71). In addition, Japanese culture and that of its managers and firms scores high on uncertainty avoidance (Hofstede, 
1980), which result in higher numbers of JVs and WOSs compared to acquisitions, which are therefore carried out later if at all (Kogut and Singh, 1988).

One of the longstanding views on entry modes considers that they sit on a continuum of decreasing control and resource commitment, and of increasing risk (Anderson \& Gatignon, 1986; Erramilli \& Rao, 1990). Anderson and Gatignon (1986), for instance, list 17 modes that are further divided among high, medium, and low-control forms. Some scholars separate these modes depending on whether they are contract- or equity-based; the former consists of licensing, franchising, distribution, supply agreements, technical assistance, and management contracts, while the latter include joint-ventures (JVs) and wholly-owned subsidiaries (WOSs) (Hennart, 1988, 1989, 2000). Hennart (2000) argues that this categorization rests on whether input providers are paid according to a price defined before or after the business transaction. JVs and WOSs are in the same category since input providers are paid ex post from the profits of the endeavor, whereas contracts stipulate prices ex ante. Hennart (2000) contends that a firm will select a JV over a WOS when it cannot easily acquire local factors of production to complement its own assets, such as in the case of knowledge-based assets.

Past research has found that Japanese firms use higher levels of equity ownership when investing in the West, including the US, compared to the East, putting a higher priority on knowledge transfers and learning opportunities (Pak and Park, 2005). These results are consistent with earlier findings which established that greenfield investments performed better than JVs, and that acquisitions had mixed results for Japanese FDI in Europe (Nitsch et al., 1996). Furthermore, Japanese-Japanese JVs involving a partner with prior experience in the host country exhibited better performance than those with a local partner or even WOSs in the Brazilian context (Ogasavara and Hoshino, 2007). Japanese firms are thus expected to follow a sequence of gradual and incremental commitments starting with WOSs, followed by JVs and acquisitions (Hypothesis 2).

\section{METHODOLOGY AND RESULTS}

\section{Sample}

A total of 14 interviews were conducted with top managers of Japanese affiliated firms in the state of Georgia. Georgia was selected because, as of 2017, Japan was the top foreign direct investor nation in the state based on total dollar value of investment (Georgia Department of Economic Development, 2017), counting more than 500 Japanese facilities employing about 37,000 workers (JASG, 2019). Employment at Japanese affiliates in the US is heavily skewed towards manufacturing and wholesale trade (BEA, 2019), driven by Japanese automakers, their suppliers, and many other related businesses (Government of Japan, 2017). The Japan-America Society of Georgia states that "Georgia is regarded as the center of Japanese industry in the US Southeast. Japanese-affiliated companies have invested USD10.4 billion in Georgia" (JASG, 2019).

Of the several hundred Japanese firms in Atlanta's metropolitan area, only those in the manufacturing or wholesale trade industries and with a presence in the US of at least 20 years were invited to allow more variety and depth of establishment modes and motives over time. Subsequently, the purpose of this research was stated when contacting potential firms, explicitly seeking top managers with knowledge pertaining to their organization's investment history and motives in the US Southeast market. Indeed, the issue of corporate memory for potential interviewees was of concern as some managers that were contacted were not present when their business unit was established or underwent a change in corporate form, having 
therefore only ambiguous knowledge of the strategic reasons that had driven their firm to select a specific establishment mode or location within the country.

The 14 companies included in this research are either in the manufacturing $(n=10)$ or wholesale trade industries $(n=4)$, as specified by their North American Industry Classification System (NAICS) code. Those classified in manufacturing may also engage in wholesale trade, while those in wholesale trade do not manufacture in the US. Table 1 details the 14 companies' name, years and order of sequence of establishment mode sequence: Honda Lock America Co., Ltd., a tier one automotive parts manufacturer; IKO International, Inc., a needle roller bearings, linear motion products and mechatronic products wholesale trader; Kubota Manufacturing of America, a commercial and residential-use tractors, rough-terrain vehicles manufacturer; Murata Electronics North America, a ceramic-based passive electronic components and devices wholesale trader; Nichiha USA, a fiber cement sidings manufacturer; Nidec Elesys Americas Corp., an automotive electronic safety systems manufacturer; OTC Daihen, Inc., a welding and cutting equipment, torches, and robots manufacturer; Panasonic Automotive Systems Company of America, an OEM audio, video, navigation, and information products and systems manufacturer for the automotive industry; TDK Corporation of America, a ceramic-based passive electronic components and devices manufacturer; Toppan Interamerica, Inc., a manufacturer of design and printing for industrial materials; Toto USA, Inc., a plumbing manufacturer; Toyo Ink Group, a printing inks, colorants, functional materials wholesale trader; Yanmar America Corporation, a diesel engines, agricultural and construction equipment wholesale trader; YKK Corporation of America, a fastening and architectural products manufacturer. It is important to note that the size of the sample doesn't allow the separation of manufacturers and wholesale traders.

TABLE 1

Companies surveyed, with entry modes, years, and sequence

\begin{tabular}{|c|c|c|c|c|c|c|c|c|c|c|}
\hline & \multicolumn{2}{|c|}{ Sales office } & \multicolumn{2}{|c|}{$\begin{array}{c}\text { Factory/ } \\
\text { Parts Center }\end{array}$} & \multicolumn{2}{|c|}{ Acquisition } & \multicolumn{2}{|c|}{ Buy-out } & \multicolumn{2}{|c|}{$\begin{array}{c}\text { Joint- } \\
\text { Venture }\end{array}$} \\
\hline & \# & Year & \# & Year & \# & Year & $\#$ & Year & \# & Year \\
\hline 1. Honda Lock America Co., Ltd. & & & 3 & 1999 & & & 2 & 1997 & 1 & 1988 \\
\hline 2. IKO International, Inc. & 1 & 1971 & & & & & & & & \\
\hline 3. Kubota Manufacturing of America & 1 & 1972 & 2 & 1988 & & & & & & \\
\hline 4. Murata Electronics North America & 1 & 1963 & 2 & 1973 & 3 & 1973 & & & & \\
\hline 5. Nichiha USA & 1 & 1998 & 2 & 2008 & & & & & & \\
\hline 6. Nidec Elesys Americas Corp. & 1 & 1976 & & & 4 & 1991 & 3 & 1984 & 2 & 1978 \\
\hline 7. OTC Daihen, Inc. & 1 & 1979 & & & & & & & & \\
\hline $\begin{array}{l}\text { 8. Panasonic Automotive Systems } \\
\text { Company of America }\end{array}$ & 1 & 1975 & 2 & 1987 & & & & & & \\
\hline 9. TDK Corporation of America & 1 & 1959 & 2 & 1984 & 4 & 1989 & 5 & 1992 & 3 & 1987 \\
\hline 10. Toppan Interamerica, Inc. & 1 & 1964 & 3 & 1988 & 2 & 1988 & & & & \\
\hline 11. Toto USA, Inc. & 1 & 1986 & 3 & 1996 & 2 & 1990 & & & & \\
\hline 12. Toyo Ink. Group & 2 & 1976 & 4 & 2008 & 5 & 2010 & 3 & 2007 & 1 & 1975 \\
\hline 13. Yanmar America Corporation & 2 & 1981 & 3 & 1989 & & & & & 1 & 1979 \\
\hline 14. YKK Corporation of America & 1 & 1960 & 2 & 1974 & 3 & 1987 & & & & \\
\hline Average ranking (sequence) & 1.2 & & 2.5 & & 3.3 & & 3.3 & & 1.6 & \\
\hline Ranking (sequence) & 1 & & 3 & & 4 & & 4 & & 2 & \\
\hline
\end{tabular}

\# denotes order in establishment sequence 


\section{Method}

This research uses qualitative research interviews whose contents was then evaluated using NVivo 12 Pro, a dedicated application for analyzing qualitative and unstructured data sets, such as those drawn from interviews and open-ended questionnaires (QSR International, 2018). This particular method is relevant when aiming to describe and understand meaning from interviewees with specific subject matter expertise (Kvale, 1996). These interviews then led to the writing of short case-studies which are suitable for the development of theory (Eisenhardt, 1989). The same standardized, open-ended interview questions were asked to each interviewee to make comparisons possible over meetings which lasted between 60 and 90 minutes.

Interview questions consisted of background information about the interviewee, a general description of the business unit or units of the focal firm, their history and establishment modes in the US, and investment motives based on Dunning $(1993,2000)$. Each interview summary was then coded into NVivo 12 Pro. A third-party not involved in this research was asked to recode $10 \%$ of the data (two interview summaries out of 14) to evaluate inter-rater reliability. An average 95\% agreement and Cohen's Kappa coefficient values higher than 0.7 confirmed inter-rater reliability (LeBreton and Senter, 2008).

Parsing through the histories of these firms was no easy fit as most are part of medium or large Japanese groups sometimes with hundreds of subsidiaries in the US, several product divisions, and cross-shareholding. I was decided to focus on the subsidiaries or business units visited and interviewed, tracking their origins and corporate forms over the years by crosschecking primary information with secondary data from publicly-available sources.

Hypothesis 1 was tested by evaluating the entry mode sequence of each firm, while Hypothesis 2 was assessed by examining the reported types of firm-level FDI motives by each interviewee.

\section{Results}

Table 1 provides information about these companies' sequence of establishment. The year is that of a specific establishment mode when it was first used by the firm; some companies may have opened several sales offices, factories or invested in many joint-ventures over the years, but only the year of each first instance is recorded, and a rank is then calculated based on these years of first occurrence. The bottom row shows the sequence of these establishment modes when first used. Overall, these companies started with a sales office, followed by a joint-venture, a factory or parts center, and last an acquisition of a local firm or buying out their JV partner. This prevailing sequence provides support for Hypothesis 1.

Table 2 displays the coding frequency of entry motives. Based on the number of references to specific FDI drivers, the most prevalent first-order level motive for Japanese FDI in the US is market-seeking (76), followed by efficiency-seeking (55), strategic-assetseeking (21) and resource-seeking (12). And because each first-order level motive category does not consist of the same number of second-order level motives, average coding frequency for each first-order level were also computed (dividing the total number of references by the number of second-order categories) and found that they still hold the same rank: marketseeking (average coding frequency of 10), followed by efficiency-seeking (7), strategic-assetseeking (5) and resource-seeking (3). These results suggest that Hypothesis 2 is only partially supported. 
TABLE 2

Coding frequency for entry motives

\begin{tabular}{|c|c|c|c|c|}
\hline & Files & $\%$ & Ref. & $\%$ \\
\hline \multicolumn{5}{|l|}{ Market-seeking } \\
\hline Follow competitors & 0 & $0 \%$ & 0 & $0 \%$ \\
\hline Target market lack of competition & 0 & $0 \%$ & 0 & $0 \%$ \\
\hline Gain first-mover advantage & 1 & $7 \%$ & 1 & $1 \%$ \\
\hline Competition at home & 1 & $7 \%$ & 1 & $1 \%$ \\
\hline Target market's unmet demand & 3 & $21 \%$ & 4 & $5 \%$ \\
\hline Follow customers & 7 & $50 \%$ & 10 & $13 \%$ \\
\hline Target market growth rate & 13 & $93 \%$ & 27 & $36 \%$ \\
\hline \multirow[t]{2}{*}{ Target market size } & 14 & $100 \%$ & 33 & $43 \%$ \\
\hline & 39 & & 76 & $100 \%$ \\
\hline \multicolumn{5}{|l|}{ Resource-seeking } \\
\hline Create an export base to other countries & 1 & $7 \%$ & 1 & $8 \%$ \\
\hline Access production input & 2 & $14 \%$ & 2 & $17 \%$ \\
\hline Take advantage of institutional and legal environment & 2 & $14 \%$ & 3 & $25 \%$ \\
\hline \multirow[t]{2}{*}{ Take advantage of infrastructure } & 5 & $36 \%$ & 6 & $50 \%$ \\
\hline & 10 & & 12 & $100 \%$ \\
\hline \multicolumn{5}{|l|}{ Efficiency-seeking } \\
\hline Lower the total tax burden & 0 & $0 \%$ & 0 & $0 \%$ \\
\hline Diversify risks & 2 & $14 \%$ & 2 & $4 \%$ \\
\hline Avoid quotas, tariffs, or other trade barriers & 3 & $21 \%$ & 3 & $5 \%$ \\
\hline Target market government incentives & 6 & $43 \%$ & 6 & $12 \%$ \\
\hline Economy of scale and or scope & 6 & $43 \%$ & 7 & $13 \%$ \\
\hline Differences in consumer patterns between countries & 7 & $50 \%$ & 8 & $15 \%$ \\
\hline Integration within existing value-chain & 8 & $57 \%$ & 14 & $25 \%$ \\
\hline \multirow[t]{2}{*}{ Reduce transaction/ transportation costs with physical presence } & 12 & $86 \%$ & 17 & $31 \%$ \\
\hline & 42 & & 55 & $100 \%$ \\
\hline \multicolumn{5}{|l|}{ Strategic asset-seeking } \\
\hline Better access to skilled labor & 1 & $7 \%$ & 1 & $5 \%$ \\
\hline Gain knowledge about the target market & 3 & $21 \%$ & 4 & $19 \%$ \\
\hline Reduce or prevent competition by acquiring whole or part of a company & 4 & $29 \%$ & 6 & $29 \%$ \\
\hline \multirow[t]{2}{*}{ Gain technological knowledge (patents, employee skills, systems, etc.) } & 6 & $43 \%$ & 10 & $48 \%$ \\
\hline & 14 & & 21 & $100 \%$ \\
\hline
\end{tabular}

In more detail, it is important to recognize the top second-order level motives for each of the four FDI entry motives by looking at the recorded number of cases (i.e. firms) for each of them: among market-seeking motives, target market size $(14,100 \%)$ and growth rate $(13$, 93\%); among efficiency-seeking motives, reducing transaction and/or transportation costs with a physical presence $(12,86 \%)$, integration within existing value-chain $(8,57 \%)$, and differences in consumer patterns between countries (7, 50\%); among strategic asset-seeking motives, gaining technological knowledge (patents, employee skills, systems, etc.) $(6,43 \%)$; and among resource-seeking motives, taking advantage of infrastructure $(5,36 \%)$.

Table 3 presents selected statements reflecting the coding of the most dominant motives for Japanese FDI among the 14 companies interviewed. 


\section{TABLE 3}

\section{Entry motives illustrated by interview summary statements}

Market-seeking motives

Target market

"When the factory opened in Peachtree City, GA in 1987 to be closer to USsize based customers, several Japanese car manufacturers had opened assembly plants in $(14,100 \%)$ nearby states, such as Honda in Ohio and Toyota in Kentucky."

Panasonic Automotive Systems Company of America

Due to its limited size and lack of manufacturing in the US, IKO focuses on supplying low to mid volumes for US-based SMEs and MROs [Maintenance, Repair, and Overhaul] with after-market components. In the United States, $90 \%$ of its customers are American and 10\% Japanese, but because it sells to US-based distributors, end-users of its products are 70\% American and 30\% Japanese. The American market is very large for our business."

IKO International, Inc.

Growth rate $(13,93 \%)$
"The Atlanta metropolitan area has been experiencing impressive residential growth: the population grew by $35 \%$ from 1.9 million in 1980 to 2.5 million in 1990, by $34 \%$ between 1990 and 2000, and by $20 \%$ between 2000 and 2010, and eventually reaching 5.9 million in 2017 . This population growth has spurred commercial developments that the company wished to exploit."

\section{Nichiha USA}

"Yanmar started by exporting compact utility tractors of $40 \mathrm{hp}$ or less used for cutting lawns or doing light construction work on ranches to the US in the late 1960s. (...) In 1977, Yanmar signed an OEM contract with John Deere to supply compact tractors to North America and other countries under the John Deere brand. (...) In 1986, production of compact tractors for John Deere reached a total of 100,000 units."

\section{Yanmar America Corporation}

"OTC America entered the robotic business in North America in 1983 supplying Japanese auto makers' new US operations, and in 1985, it became the official OEM supplier of robot maker Miller Electric Co."

OTC Daihen, Inc.

\section{Efficiency-seeking motives}

Reducing transaction and/or transportation costs with a physical presence $(12,86 \%)$
"In order to provide better service to customers with shorter design lead-time and stable production, TIA [Toppan Interamerica] ramped up local production, relying less on imports from Japan. The strong yen of 2008 also contributed to such production shift in order to remain competitive."

Toppan Interamerica, Inc.

"In 1984 TDK launched its Components Engineering Laboratory in Los Angeles, CA. In addition to customization, the new lab reduced the time required to go from product development to full-scale production."

TDK Corporation of America 
Integration "The rationale for the acquisition of Elesys was the need to ever more integrate within existing electric power steering (EPS) motors with electronic control unit (power-pack). By value-chain combining Nidec's EPS motors with Elesys' electronic control units (ECU), the $(8,57 \%) \quad$ motor business had the potential to be transformed into a module business, with Nidec Elesys grabbing a larger share of the business worldwide as an integrated supplier."

\section{Nidec Elesys Americas Corp.}

"That location was picked because of lower labors costs and for its relative proximity to Honda of America Manufacturing's Marysville, $\mathrm{OH}$ auto plant established in 1982, the Anna, OH engine plant started in 1985, and the East Liberty, OH auto plant opened in 1989."

Honda Lock America Co., Ltd.

Differences in consumer patterns between countries $(7,50 \%)$
"As Kubota's North American production base for tractors, KMA [Kubota Manufacturing of America] began adding different products such as lawn and garden tractors, general-use subcompact tractors, zero turn mid-mount mowers, allpurpose residential tractors, and rough-terrain vehicles (RTVs), which were specifically developed for the US market."

\section{Kubota Manufacturing of America}

"The parts designed and manufactured at the Bremen, GA factory are specific to vehicles assembled and sold in the US market. For instance, lower-grade US vehicles use fixed door mirrors, while Japan domestic market vehicles all use foldable door mirrors."

Honda Lock America Co., Ltd.

\section{Strategic asset-seeking motives}

\section{Gaining} technological knowledge (patents, employee skills, systems, etc.)

$(6,43 \%)$
"However, Toyo Ink products, while of high quality, proved too expensive, and Toyo Ink decided in 2010 to acquire Moorpark, CA-based Fluid Ink Technology's brands and intellectual property ink formulations specifically for the US market."

Toyo Ink. Group

"In 1980, Murata went on to acquire one of its main competitors, Erie Technological Products (Erie Tech) of Canada. Erie Tech was the main player for ceramic chip capacitors in the US at the time. That acquisition expanded Murata's US operations to 8 locations in North America, including Canada and Mexico."

Murata Electronics North America

\section{Resource-seeking motives}

Taking advantage of infrastructure $(5,36 \%)$
"In 1990, TOTO purchased ELJER's aging Lakewood, GA toilet factory. The factory benefited from the proximity of clay shipped by rail from Tennessee."

Toto USA, Inc.

"Most products imported from Asia are shipped through Savannah, GA, a deepsea port, which accommodate large container ships."

Nichiha USA 


\section{DISCUSSION AND CONCLUSION}

\section{Investment Motives}

Japanese firms in manufacturing and wholesale trade investing in the US Southeast have been using several establishment modes ranging from sales office, joint-venture, factory or parts center, buy-out, to outright acquisition. This sequence is consistent with Johanson and Vahlne (1997)'s internationalization process model whereby gradual and incremental market commitments are made over time as they gain more knowledge and experience. These establishments modes are selected on the basis of control, resource commitment and risk (Anderson \& Gatignon, 1986; Erramilli \& Rao, 1990).

On a first-order level, text analysis results indicate that Japanese firms in these industries invest in the US Southeast seeking first a market for their intermediate or finished products and second factors to boost efficiency. On a second-order level, more than half of the firms in this research reported the main motives to be target market size and growth rate, reducing transaction and/or transportation costs, and integration within existing value-chains. These results suggest that Japanese firms in manufacturing and wholesale trade still consider the US an attractive terminal or intermediate market where they have been integrating their activities over time. Contrary to the findings of Pak and Park (2005), most of the Japanese investors interviewed for this research were not found to be seeking learning opportunities or to be displaying asset-seeking, as opposed to asset-exploiting, behavior in the US Southeast. Only those which had established a joint-venture at some point sought to benefit from their US-based partner. This can be partly explained by the fact that all the firms included in this study were all in the manufacturing and wholesale trade industries extending their market using well-honed core-competencies. These results are in line with those of Kogut and Chang (1991)'s stated earlier.

It is also worth looking at the missing investment motives or those motives mentioned by less than $10 \%$ of respondents (fewer than 2 interviewees); these omitted motives include following competitors, the target market's lack of competition, gaining first-mover advantage, competition at home, creating an export base to other countries, lowering the total tax burden, and better access to skilled labor (Table 2). Again, the specific businesses - automotive, printing, plumbing, and fastening - of the firms included in the survey should inform our interpretation. The lack of concern about local competition can be explained by the reported size and growth rate of the markets they are serving in the US Southeast. In turn, creating an export base may be irrelevant for these Japanese manufacturing companies supplying a sustainable market with localized product tailored to US needs. Last, these companies often rely on technology developed in Japan and transferred and applied by a few Japanese expatriates, therefore negating the need for local skilled labor. These subsidiaries do not perform sophisticated-enough functions replacing home-based research and development to warrant large numbers of expatriates and local skilled-labor (Oki, 2013).

The findings here should be discussed considering the regional nature of the sampled investments all located in the US Southeast. Statistics on activities of MNEs by industry and state are not readily available and for instance, the U.S. Bureau of Economic Analysis (BEA) only offers data either by industry or state for affiliates from individual countries of ultimate ownership. As of 2016, at the national level, Japanese affiliated companies employed about 922,000 people in the US, of which $44 \%$ in manufacturing $(409,000)$ and $29 \%$ in wholesale trade $(270,800)$, by far the two highest contributors to employment (BEA, 2019). Although data by state for Japanese investment exists (such as that provided by Toyo Keizai), an estimate was instead calculated based on the list of Japanese subsidiaries in the US extracted from the Directory of Corporate Affiliations. This database, published by LexisNexis, is 
considered one of the most complete sources of information on firms and their affiliates. It lists companies with revenues over USD 1 million and at least 300 employees, as well as their NAICS industry codes. Of the 136 entries of Japanese affiliates in Georgia as of November 2018, 56\% were in manufacturing (codes 31-33) and 18\% in wholesale trade (code 42), for a total of $74 \%$. These are to be contrasted with the 3,574 Japanese affiliates in the US nationwide, of which $46 \%$ were in manufacturing and $22 \%$ in wholesale trade, totaling $67 \%$. Therefore, the state of Georgia counts significantly more Japanese affiliates in manufacturing $(+22 \%)$ and about the same in wholesale trade $(+15 \%)$ compared to the US national average. However, this approximation only considers larger firms, while two firms included in this research are smaller (IKO and OTC Daihen) and would thus not be included in these estimates.

\section{Joint-Venture Establishment}

Hennart (1991) has argued that Japanese firms select a joint-venture establishment mode over a wholly-owned subsidiary whenever they want to access local intermediate inputs which incur high transaction costs, such as production inputs, product or market knowledge, and distribution. While it is impossible to verify this argument based on this limited sample of companies which used multiple establishment modes over time, the cases of three of the five firms which set up joint-ventures can be examined.

Honda-Lock Japan (HL-J) and the American firm All-Lock Co. entered into a 50:50 joint-venture in Selma, AL, establishing Honda All-Lock Manufacturing Co., Inc in 1988. All-Lock was then an established maker of a broad line of original equipment manufacturer (OEM) and aftermarket switches, locks, and keys for the marine, automotive and industrial markets, already supplying Honda in the US. In 1997, the joint venture was discontinued, and the Alabama operation became 100\%-owned by Honda-Lock Japan, and the name was changed to HL-A Company, Inc. The joint-venture was established because Honda wanted to further integrate the manufacturing of OEM parts in the US, in the context of increasing production at its three Ohio auto plants opened in the 1980s. All-Lock was already supplying Honda in the US but was short of cash for further investment supplying Honda. Consistent with Hennart (1991) and Erramilli and Rao (1993), Honda had a low level of asset specificity, since it wanted to acquire the knowledge of its supplier (Klein, 1989) and therefore favored a joint-venture mode and later bought out the entity.

Yanmar began making test sales of compact utility tractors through a trading company in 1974. Indeed, Yanmar had noticed the potential and the underserved market for small tractors of less than 40 horsepower designed for lawn cutting or light construction work (Yanmar, 2016). With positive results, Yanmar Tractor (USA) Inc. was established in 1979 jointly with the trading company to increase its presence and grow sales. Yanmar was already importing large John Deere tractors to Japan. In this case, Yanmar used an initial entry method favored by Japanese companies, through a general trading company which possessed extensive international experience helping with market input and distribution, and financing part of the venture with their own equity (Hennart, 1988; Delios and Beamish, 1999). Jointventures do not always involve a local partner in the case of Japanese firms, as the other investor can be another Japanese firm such as a trading company.

TDK created in 1987 a joint-venture with the American company Allen-Bradley to produce motor magnets for the automobile industry in Oklahoma. TDK took advantage of its partner's longstanding relationship with American automakers, while Allen-Bradley benefited from TDK's magnetics expertise. In 1992, TDK bought Allen Bradley's interest in the plant and changed the name to TDK Ferrites Corporation. This case fits very well with Hennart 
(1991)'s argument whereby TDK sought the market knowledge and distribution network of its American partner and eventually bought out the venture.

\section{Policy Implications}

The goal of Japanese FDI in the US, especially high-value added production, is no longer to bypass tariffs as it was in the 1980s (Eaton and Tamura, 1994), but it is still part of a complex industrial network of relations which drives further investment. Japanese firms in manufacturing and wholesale trade were found to still favor a classic sequence of gradual and incremental market commitment consistent with previous research (Johanson and Vahlne, 1997). These affiliates from Japan are attracted to the US Southeast for its domestic market and industrial clusters, seeking to increase sales and further integrate their value-chains. States which attract large investments from Japanese firms can attract their suppliers, as well as suppliers to Japanese firms located in neighboring states, benefiting from stable and lasting supplier-customer relationships (Helper and Sako, 1995).

Another contribution of this study is directed at policy-makers at the state level. Although less than half of the firms mentioned target market government incentives as a motive for FDI, it is likely that they had decided to set up operations in the US and that these incentives merely informed the location of their operations in the country. It follows that states should try to capture Japanese FDI in manufacturing and wholesale trade by considering which motives they can control or affect. While it is doubtful that states can directly influence market size or growth rate, they should instead address value-chain integration by creating industrial clusters or parks and encouraging investments concentrated in specific industries or activities. While manufacturing density is positively related to FDI (Coughlin, Terza, and Arromdee, 1991), rather than attracting investment into an established area, many Japanese firms bring a web of suppliers with them, creating industrial clusters in previously agricultural or textile-dominant areas. Similarly, while skilled labor and tax incentives may not matter as much considering the large and growing markets and the valuechain and cluster integration these companies are seeking, they may tip the scale in the choice of state to enter.

\section{REFERENCES}

Anderson, E., \& Gatignon, H. (1986). Modes of foreign entry: A transaction cost analysis and propositions. Journal of International Business Studies, 17(3): 1-26.

Barboza, D. 2010. China passes Japan as second-largest economy. The New York Times, August 15.

Barney, J. (1991). Firm resources and sustained competitive advantage. Journal of Management, 17(1): 99-120.

BEA. 2019. Foreign direct investment in the United States. U.S. Bureau of Economic Analysis. Available at: https://apps.bea.gov/iTable/index_MNC.cfm

Brouthers, K. D., \& Hennart, J. F. (2007). Boundaries of the firm: Insights from international entry mode research. Journal of Management, 33(3): 395-425.

Buckley, P. J. 1982. Multinational Enterprises and Economic Analysis. London: Cambridge University Press.

Buckley, P. J. 1988. The limits of explanation: Testing the internalization theory of the multinational enterprise. Journal of international business studies, 19(2): 181-193. 
Buckley, P. J., \& Casson, M. C. 1976. The future of the multinational enterprise. London: Macmillan.

Caves, R. E. 1971. International corporations: The industrial economics of foreign investment. Economica, 38(149): 1-27.

Chang, S. J., \& Rosenzweig, P. M. 2001. The choice of entry mode in sequential foreign direct investment. Strategic Management Journal, 22(8): 747-776.

Cortez, M. 2017. Foreign Direct Investment in the United States: Update to 2017 Report, ESA Issue Brief \#06-17, Office of The Chief Economist, Economics and Statistics Administration, U.S. Department of Commerce, October 3, 2017. Available at: http://www.esa.doc.gov/sites/default/files/FDIUS2017update.pdf

Coughlin, C. C., Terza, J. V., \& Arromdee, V. 1991. State characteristics and the location of foreign direct investment within the United States. The Review of Economics and Statistics, 73(4): 675-683.

Davidson, W. H. 1980. The location of foreign direct investment activity: Country characteristics and experience effects. Journal of International Business Studies, 11(2): 9-22.

Delios, A., \& Beamish, P. W. 1999. Ownership strategy of Japanese firms: Transactional, institutional, and experience influences. Strategic Management Journal, 20(10): 915933.

Drake, T. A., \& Caves, R. E. 1992. Changing determinants of Japanese foreign investment in the United States. Journal of the Japanese and International Economies, 6(3): 228246.

Dunning, J. H. 1977. Trade, location and economic activity and the multinational enterprise: A search for an eclectic approach. In B. Ohlin, P. Hesselborn, \& P. Wijkman (Eds.), The international allocation of economic activity: 395-418. London: MacMillan.

Dunning, J. H. 1980. Toward an eclectic theory of international production: Some empirical tests. Journal of International Business Studies, 11(1): 9-31.

Dunning, J. H. 1981. International Production and the Multinational Enterprise. London: George Allen \& Unwin.

Dunning, J. H. 1993. Multinational enterprise and the global economy. Wokingham: Addison Wesley.

Dunning, J. H. 1998. Location and the multinational enterprise: a neglected factor? Journal of International Business Studies, 29(1): 45-66.

Dunning, J. H. 2000. The eclectic paradigm as an envelope for economic and business theories of MNE activity. International Business Review, 9(2): 163-190.

Eaton, J., \& Tamura, A. 1994. Bilateralism and regionalism in Japanese and US trade and direct foreign investment patterns. Journal of the Japanese and International Economies, 8(4): 478-510.

Eisenhardt, K. M. 1989. Building theories from case study research. Academy of Management Review, 14(4): 532-550.

Erramilli, M. K., \& Rao, C. P. 1993. Service firms' international entry-mode choice: A modified transaction-cost analysis approach. The Journal of Marketing, 57(3): 19-38. 
Froot, K. A., \& Stein, J. C. 1991. Exchange rates and foreign direct investment: an imperfect capital markets approach. The Quarterly Journal of Economics, 106(4): 1191-1217.

Georgia Department of Economic Development. 2017. Georgia Delegation Celebrates Southeast U.S.-Japan Partnership. Georgia Department of Economic Development. Available at: https://www.georgia.org/2017/11/06/georgia-delegation-celebratessoutheast-u-s-japan-partnership

Government of Japan. 2017. Japanese companies have created 840,000 American jobs. Government of Japan. Available at: https://qz.com/942619/japanese-companies-havecreated-840000-american-jobs/

Helper, S. R., \& Sako, M. 1997. Supplier relations in Japan and the United States. Sloan Management Review, 36(3): 77-84.

Hennart, J. F. 1988. A transaction costs theory of equity joint ventures. Strategic Management Journal, 9(4): 361-374.

Hennart, J. F. 1991. The transaction costs theory of joint ventures: An empirical study of Japanese subsidiaries in the United States. Management Science, 37(4): 483-497.

Hennart, J. F. 2016. Special Essay: Do we really understand why there are multinational enterprises? A look at early Japanese foreign direct investment in the United States. Japan MNE Insights, 2(2): 1-5.

Hofstede, G. 1980. Motivation, leadership, and organization: do American theories apply abroad? Organizational Dynamics, 9(1), 42-63.

Hong, E., Lee, I. H. I., \& Makino, S. 2018. Outbound Foreign Direct Investment (FDI) Motivation and Domestic Employment by Multinational Enterprises MNEs. Journal of International Management, in press.

Hymer, S. 1970. The efficiency (contradictions) of multinational corporations. The American Economic Review, 60(2): 441-448.

JASG. 2019. Japan-Georgia Relationship. Japan-America Society of Georgia. Available at: http://www.jasgeorgia.org/Japan-\&-Georgia-Relationship

JETRO. 2018. 1996-2017 FDI stock (Based on International Investment Position, net), Japanese Trade and Investment Statistics. Japan External Trade Organization. Available at: https://www.jetro.go.jp/en/reports/statistics.html

Johanson, J., \& Vahlne, J. E. 1977. The internationalization process of the firm - a model of knowledge development and increasing foreign market commitments. Journal of International Business Studies, 8(1): 23-32.

Johanson, J., \& Wiedersheim-Paul, F. 1975. The internationalization of the firm - four Swedish cases. Journal of Management Studies, 12(3): 305-323.

Kitao, S. 2015. Fiscal cost of demographic transition in Japan. Journal of Economic Dynamics and Control, 54: 37-58.

Kogut, B., \& Chang, S. J. 1991. Technological capabilities and Japanese foreign direct investment in the United States. The Review of Economics and Statistics, 73(3): 401413.

Kogut, B., \& Singh, H. 1988. The effect of national culture on the choice of entry mode. Journal of International Business Studies, 19(3), 411-432. 
Kvale, S. 1996. Interviews: An Introduction to Qualitative Research Interviewing. Thousand oaks, CA: Sage Publications.

LeBreton, J. M., \& Senter, J. L. 2008. Answers to 20 questions about interrater reliability and interrater agreement. Organizational Research Methods, 11(4): 815-852.

Magnier-Watanabe, R., \& Lemaire, J. P. 2018. Inbound foreign direct investment in Japan: A typology. International Business Review, 27(2): 431-442.

Mihut, M. I. 2014. Plaza Accord and the "Explosion" of the Japanese FDI. Procedia Economics and Finance, 15: 721-729.

Morgan, R. E., \& Katsikeas, C. S. 1997. Theories of international trade, foreign direct investment and firm internationalization: a critique. Management Decision, 35(1): 6878.

Murphy, R. T. 2010. A loyal retainer? Japan, capitalism, and the perpetuation of American hegemony. The Asia-Pacific Journal, 41(3): 1-10.

Nitsch, D., Beamish, P., \& Makino, S. 1996. Entry mode and performance of Japanese FDI in Western Europe. MIR: Management International Review, 36(1), 27-43.

Ogasavara, M. H., \& Hoshino, Y. 2007. The impact of ownership, internalization, and entry mode on Japanese subsidiaries' performance in Brazil. Japan and the World Economy, 19(1), 1-25.

QSR International. 2018. What is NVivo? QSR International. Available at: https://www.qsrinternational.com/nvivo/what-is-nvivo

Rao, T. R., \& Naidu, G. M. 1993. Are the stages of internationalization empirically supportable? Journal of Global marketing, 6(1-2): 147-170.

Siddiqui, K. 2009. Japan's economic recession. Research in Applied Economics, 1(1): E9.

Trending Economics. 2019. Japan General Government Gross Debt to GDP. Trending Economics. at: https://tradingeconomics.com/japan/government-debt-to-gdp

World Bank 2018. Exports of goods and services (constant 2010 US\$). The World Bank. Available at: https://data.worldbank.org/indicator/NE.EXP.GNFS.KD?end=2016\&locations $=$ JP\&start $=1996$ 